\title{
SUPPLY CHAIN AND TRADE PRACTICE - THE OUTLOOK FOR BANANAS IN ASSAM
}

\author{
Tanmoy Ray \\ Research scholar, Department of Commerce, Gauhati University, Assam, India
}

\begin{abstract}
India is moving towards manufacturing sector from service sector, but the Agricultural sector still plays a vital role in the Indian Economy. Banana, known to be originated in South-East Asian region, is one of the most important staple crops in the world. It is cultivated across the world owing to its significance in terms of household food, nutrition, and social security. The agricultural produced bananas are ample to ensure population food sufficiency as well as income for rural farmers. Assam, a state from the north-east corner of India. The land, blessed with ample natural resources where people depend mostly on agricultural crops. Assam was among the top ten banana producing state in India once, but due to late technological and scientific adoption of modern agricultural methods and other factors pushed it back. India enjoys its position, as the largest volume of Banana producer in the world, but in terms of export it comes nowhere in the topper list. The trade supply chain of fruit and vegetables is short, which means that the products are sold near the production site or at local markets.
\end{abstract}

Key words: Banana, Supply Chain, Trade, Social Security, Agricultural Crop

Cite this Article: Tanmoy Ray, Supply Chain and Trade Practice - The Outlook for Bananas in Assam, International Journal of Management, 11(12), 2020, pp 1448-1454. http://iaeme.com/Home/issue/IJM?Volume=11\&Issue=12

\section{INTRODUCTION}

Banana is one of the most important staple crops in the world. It is critical for food security in many tropical countries. It is consumed in almost all the countries of the world even though production is tilted and few countries account for maximum of the world's production. Since the 1900s, banana has played a central role in the economies of a number of countries especially in Central and Latin America. Ironically, India, the largest producer of banana hardly has significant share in the international banana trade. India produces roughly about 30 Million tons (FAO, 2018), while China is the ranks second with 13 Million tons. In 2017 alone, 22.7 million tonnes of bananas, excluding were traded, representing almost $20 \%$ of global production that year. The value of this trade was worth USD 11 billion, which is higher than the export value of any other exported fruit. While Asia is the largest banana-producing region, Latin America and the Caribbean is the largest exporting region, responsible for 
approximately $80 \%$ of global exports. Banana farmers in India, usually individuals, who usually sell those harvests in an open domestic market to anyone i.e. traders or directly to local consumers, as long as they may get profit and cover the production costs.

\subsection{Significance of the Study}

The supply chain management practice focuses only on customer needs or the customer's perspective. The modern production perspective, especially in supply chain management, are very rare in Assam's banana trade. Since, banana demand is always about constant in India, production must adapt rapidly to changes to maintain a consistent supply in order to compete with other banana exporters in the world. The consumption markets are still on the rise, and more particularly in the emerging markets. Furthermore, the expansion of the export, temperature-controlled distribution can offer an opportunity to apply modern, more environmentally sustainable farming practices on a large scale.

\section{LITERATURE REVIEW}

Literature review is the base of understanding of subject. The literature review covers many areas related to the nature of the research questions put forward, and thus includes: Agri-food management, supply chain approaches and trade practices.

\begin{tabular}{|c|c|}
\hline $\begin{array}{l}\text { Lack of suitable post-harvest management practices may lead to a huge } \\
\text { economic loss for the banana producing regions. These practices are in use to } \\
\text { enhance its shelf life by delaying the ripening, reducing respiration rate, and } \\
\text { controlling the disease, causing organisms, during transport and storage. An } \\
\text { integrated approach can ensure product safety and quality that reaches the } \\
\text { consumer, residing far away from the production area. }\end{array}$ & $\begin{array}{l}\text { Debabandya } \\
\text { Mohapatra et al., } \\
2010\end{array}$ \\
\hline $\begin{array}{l}\text { Financial, environmental, farming, natural and personal risk and spoilage factors } \\
\text { were the important problem factors in the production of banana. }\end{array}$ & $\begin{array}{l}\text { Geetha and Meena, } \\
2010\end{array}$ \\
\hline $\begin{array}{l}\text { These intermediaries in Agri value chain carry out various functions, such as } \\
\text { transfer of ownership of commodities, its movement, maintenance and } \\
\text { preservation of quantity \& quality, payment to the seller and commodity delivery } \\
\text { to the buyer. }\end{array}$ & $\begin{array}{l}\text { Halder \& Pati, } \\
2011 .\end{array}$ \\
\hline $\begin{array}{l}\text { Agricultural Produce Market Committees (APMCs) of the states are required for } \\
\text { farmers to sell fruits and vegetables in these regulated wholesale markets. The } \\
\text { regulations usually specify that transactions should occur by auctions of } \\
\text { "commission agents." These agents charge the farmers commission fees ranging } \\
\text { from } 2.5 \% \text { to } 10 \% \text {. }\end{array}$ & Singh, 2016 \\
\hline $\begin{array}{l}\text { India's food supply/value chain leads to massive wastage and inefficiencies with } \\
30 \text { to } 40 \% \text { of fruits being wasted. Customers actually end up paying } \\
\text { approximately more than } 35 \% \text { than what they could pay if supply/value chain } \\
\text { could be improved. A farmer in India gets only around } 30 \text { per cent of what the } \\
\text { customers pay at the retail store, but in USA, farmers can receive up to } 70 \% \text { and } \\
\text { wastage levels are as low as } 4-6 \% \text {. }\end{array}$ & $\begin{array}{l}\text { Reardon and } \\
\text { Minten, } 2011\end{array}$ \\
\hline $\begin{array}{l}\text { Supply chains/value chains in developing countries are often considered by } \\
\text { Western standards to be primitive, fragmented, and made of multi-layered } \\
\text { systems, particularly at the village and regional levels. }\end{array}$ & $\begin{array}{l}\text { Heilbron and } \\
\text { Roberts, } 1995\end{array}$ \\
\hline $\begin{array}{l}\text { A disruptive business model producing new values and new markets by } \\
\text { redefining the food supply chain by introducing a food hub, online marketplace, } \\
\text { facilitating an efficient connection among the producers and consumers. }\end{array}$ & Berti et al. \\
\hline
\end{tabular}




\section{OBJECTIVES}

The present paper attempts to achieve the following objectives.

- To explore the potential of Banana as an agricultural crop in India, particularly in the state of Assam.

- To study the various opportunities and constraints in Banana trade in the region.

- To assess the use of modern Supply Chain practices in the existing distribution process.

\section{METHODOLOGY}

The study is based on exploratory research method. The primary data has been collected through field survey and observation. The study aims to identify new factors that affect banana supply chain management, particularly from the trading and distribution perspective. The research is based on the conceptual framework of similar past studies and reports. Impact of Agri foods and fruits on rural livelihoods, contributing to the development of North East India in General and Assam is immense. The present study undertakes a thorough review of basic and contemporary literature available and identified the issues which are affecting the banana trade.

\subsection{The Indian Scenario}

Bananas are the world's favourite fruit and the fourth most important food crop after rice, wheat and maize. India is the world's largest producer of banana. But in terms of export, India is not even on Top 20 Banana Exporting Nations. India's social and economic development potential is proportional to new investments, technologies. India's banana export is only significant to Middle Eastern markets, where there is growing demand for bananas. The high domestic consumption, trailing supply system and any possible infrastructural and political implications are important considerations for lesser trade volumes. The Indian banana trade, therefore carry a good potential with challenges, in boosting exports in newer markets.

Table 1 Top Banana Importing Countries from India (Ministry of Commerce and Industry)

\begin{tabular}{|c|l|c|c|c|}
\hline SI. No. & \multicolumn{2}{|c|}{ Country } & \multicolumn{3}{c|}{ Values in Rs. Lacs } \\
\hline & & $2018-2019$ & $2019-2020$ & \%Growth \\
\hline 1 & IRAN & $6,805.46$ & $22,640.89$ & 232.69 \\
\hline 2 & UAE & $10,269.68$ & $14,010.08$ & 36.42 \\
\hline 3 & OMAN & $7,560.18$ & $8,222.39$ & 8.76 \\
\hline 4 & NEPAL & $3,166.95$ & $4,431.30$ & 39.92 \\
\hline 5 & SAUDI ARAB & $3,554.35$ & $4,243.28$ & 19.38 \\
\hline 6 & IRAQ & $2,674.39$ & $4,163.27$ & 55.67 \\
\hline 7 & KUWAIT & $1,624.93$ & $2,137.66$ & 31.55 \\
\hline 8 & QATAR & $1,759.56$ & $2,028.81$ & 15.3 \\
\hline 9 & BAHARAIN & 802.68 & $1,197.20$ & 49.15 \\
\hline 10 & AFGHANISTAN & $1,493.06$ & $1,134.57$ & -24.01 \\
\hline
\end{tabular}

From the above Table, it can be drawn that, India enjoys trade benefits with only two of the neighbouring countries i.e., Nepal and Afghanistan, in terms of banana trade. The observations of a significant trade are yet to be seen in Bangladesh, South Asia and other ASEAN Countries, where India has a few trade agreements. The growth of export to Middle East countries also getting immense pace. 


\subsection{The Context of Assam}

Assam along with the north East region is a land of niche fruits where banana carries diverse and new varieties being discovered in the present day. In India Tamil Nadu, Gujarat and Maharashtra are the leading banana producing states. In Assam, majority of the Banana farmers are small and marginal with a land holding less than 2 Hectares. Most of the small and marginal farmers collect the banana bunches from wild or from homesteads and sell them in the local market. Commercial cultivation of Banana is being taken up gradually over the last two decades in Assam. The most commonly grown varieties in banana in the region are Jahaji (Dwarf Cavendish), Chenichampa, Malbhog, Borjahaji (Robusta). Other Varieties includes Kanchkol, Bhimkol, Jatikol, Manjahaji, Manohar etc. are grown in the homesteads or kitchen gardens. The number of measures taken in planting to harvesting are still carried out manually. No significant packaging, grading practices or any other post-harvest practices are followed in the region.

While discussing of Bananas in Assam, the name Daranggiri certainly appears. It is located near NH17, a distance of $100 \mathrm{kms}$ West from the state capital. The market, which once had the distinction of being the largest banana retail hub in Asia. The market is supplying bananas to Nepal, Bhutan and states like West Bengal, Bihar, Jharkhand, Orissa and a part of Uttar Pradesh. The two local varieties of bananas, Malbhog, Jahaji and Chenichampa are supplied from here to states like Bengal, Bihar, Jharkhand, Odisha and parts of Uttar Pradesh. Banana bunches are sold at INR150-400 depending on the variety, demand and quality. Though banana is grown round-the-year, its peak season is from May-June to SeptemberOctober when an average of 70-80 truckloads are traded in the market of Darangiri. It is under the umbrella of Daranggiri Anchalik Unnayan Samiti, a cooperative body. Bananas from all parts of Garo Hills (Meghalaya), Assam's Goalpara and Kamrup districts are collected, wrapped in banana leaves and sold after bargaining with traders who then shipped off to various parts of the country. In 2019, with the initiative of the Assam agriculture department, it was started to export to UAE on times. But now, with the existing infrastructure and supply chain facilities, it is losing the competitive advantage. The absence of scientific cold storage facility, shed for stocking the produce, standardized packaging techniques, branding and marketing, lack of technical and financial application causes the decay.

\subsection{Supply Chain and Distribution}

Supply chain management is defined as the integration of business processes among all members of the chain, with the aim of achieving a better performance of the entire chain. Bananas are one of India's major fruit crops; they have been increasingly important not only for domestic consumption but also for overseas exports. There are many challenges for banana farming and production those are related to uncontrollable environmental factors and farmer capabilities. The first step in the establishment of the supply chain in the agroindustry is the analysis of the existing system of trade and environment (product flows, trade level, governmental policies and other circumstances), aimed at identifying the factors that are critical for the success of the supply chain. As, fresh fruit and vegetables are a challenging retail category because of the very short product lifetimes, the value chain consists of all members of the supply chain involved in the process of value creation and delivery of products to the end customers. The whole process also requires high-quality relations within the supply channel, which will result in added value for the end customer. The value chain identifies the primary activities and supporting activities performed within a single business unit. Each activity creates the costs and connections of certain activities 


\subsection{Value Chains for Banana}

The sequence of steps and participants involved in the process from production to delivery of a product to market is called a value chain.

\section{Traditional Banana Value Chain}

The traditional value chain is basically just a marketing channel because value addition at any stage is negligible. The farmers growing fruits and vegetables face problems in having access to the information related to cultivation of these crops. Storage of fruits and vegetables is a problem due to their perishability. Traditional chains do not have much value addition and majority of the farmers usually do not have access to cold storages or processing units. Traditional value chains do not have facilities like grading and packaging of produce which add tremendous value to a product.

Farmers $>$ Market Cooperative Society $>$ Wholesalers $>$ Retailer $>$ Consumer.

\section{Modern Banana Value Chain}

Modern Banana Value Chain adds to the product and requires a sophisticated system of delivery which includes storage facilities like warehouses, cold storage units, processing units, packaging services, laboratory testing facilities, market intelligence, transportation etc. Storage receipts are linked to credit too. The chain is more organised with little role for the commission agents. Retail sale is mostly done through retail stores owned mostly by corporates. The customer base is mostly urban. It caters to the market in the state, other states and also exports. Modern distribution outlets now focus on leaner supply chains to attract all types of consumers bringing down consumer retail price. There is transfer of technology from contracting agencies to farmers which aid in improving their technological knowhow. General development of agri-business farms to supply the modern distribution sector and export market. The modern value chains ensure that post-harvest losses are minimum and thereby improve farm incomes, create food security and alleviate poverty.

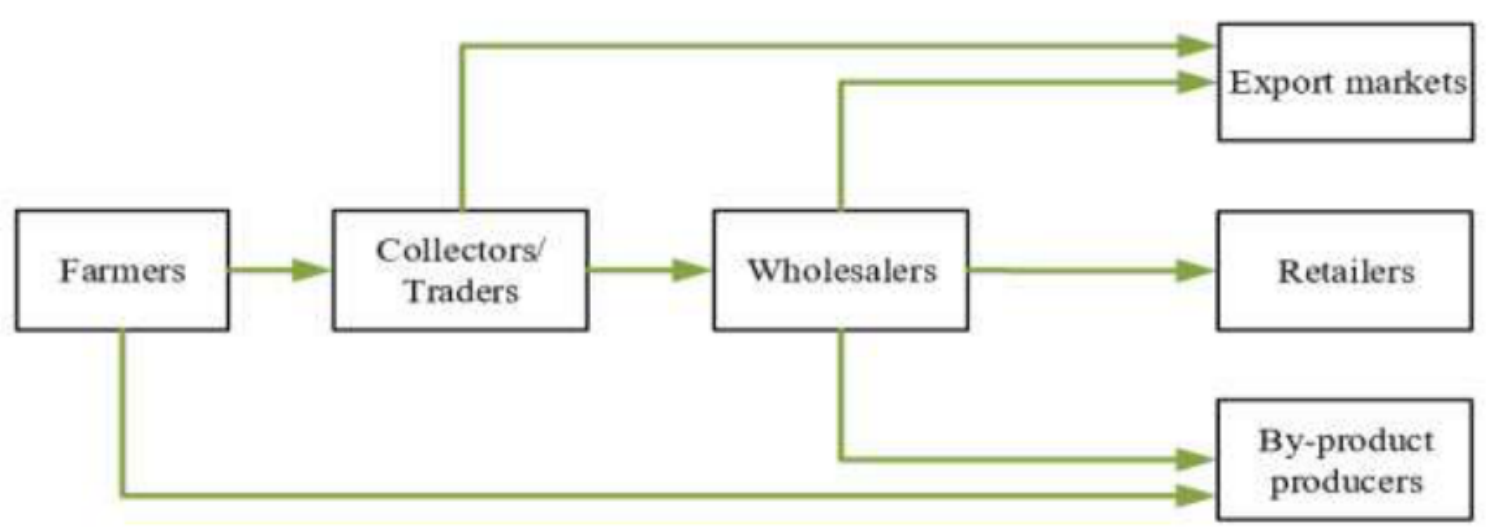

Figure 1

\section{OPPORTUNITIES}

Since the fruit is available 365 days of the year, it can be exported quickly to its export destinations. Affinity to the West Asian markets has offered a huge opportunity for Indian exporters to boost their banana consignments to the region. The global export value of the banana trade was estimated to be US $\$ 11.8$ billion in $2017-18$, with a retail value between $\$ 20$ and 25 billion. In 2018, bananas only accounted for almost $10 \%$ of the total fruits traded globally. Bananas are also number four on the list of staple crops in the world and one of the 
biggest profit makers in supermarkets, making them critical for economic and global food security. The constant availability of Banana makes it viable to process it to different valueadded products. Some Important processed products of Banana are Dried Banana slices, Banana Powder, Banana Pulps and Beverages.

\section{FINDINGS AND CONCLUSION}

The supply chain for food products is of great importance both for the overall economic sector of food products and for agriculture and rural areas. Methods or technologies must be identified and applied to create value for farmers. This also benefits consumers since they want high quality bananas and chemical-free bananas. Assam's banana industry must consider various aspects of production as importers or importing countries are currently asking for high quality bananas that are also free of any chemical residue. The export potentials to neighbouring countries like Bhutan, Nepal, Bangladesh are also substantial. Good supply chain management on the production side creates a competitive advantage for farmers and exporters since when cost decreases, they receive more profits. The supply chain of fruits and vegetables is characterized by the fact that farmers mostly sell their products at the entrances to the farm, on nearby markets and wholesale markets, while the sales to large retail chains are negligible, where they can get a constant price throughout the year. In Assam, there are no scientific storage facilities for banana, the farmers have been compelled to sell their produce immediately after harvest. Hence, there is a need to establish these facilities so that the farmers can get remunerative price for banana. The added benefits are profit increasing and operation or production improvement. With a small proportion of medium-developed producers, together with low income and short supply chain are the basic characteristics of the banana farming.

\section{REFERENCES}

[1] Berti, G.; Mulligan, C.; Yap, H. diGital food hubs as disruptive business models based on Coopetition and "shared value" for sustainability in the agri-food sector. In Global Opportunities for Entrepreneurial Growth: Coopetition and Knowledge Dynamics within and across Firms; Emerald Publishing Limited: Bingley, UK, 2017; pp. 415-438

[2] Debabandya Mohapatra, Sabyasachi Mishra and Namrata Sutar, "Banana Post Harvest Practices": Current Status and Future Prospects: A Review, Agricultural Review, 31(1): www.arccjournals.com / indianjournals.com 2010, pp.56-62

[3] Geetha, P., and Meena, A., "Problems in Production of Banana: An Analysis", B-Research, Vol.7, July-December, 2010, pp.30-31

[4] Halder, P., \& Pati, S. (2011). A Need For Paradigm Shift to Improve Supply Chain Management of Fruits \& Vegetables in India. Asian Journal of Agriculture and Rural Development, 1 (1), 1-20.

[5] Heilbron, S. and Roberts, F. (1995). Agribusiness structures: vertical Co-ordination in Australia and internationally. Rural Industries Research \& Development Co-orporation, Barton, ACT

[6] Reardon, T. and Minten, B. (2011). The quiet revolution in India's food supply chains. International Food Policy Research Institute, NEW DELHI (INDIA)

[7] Singh, S. (2016). Arthiyas in Punjab's APMC Mandis: Inadequate analysis and solutions. Economic and Political Weekly, 51(15), 69-70.

[8] Food and Agricultural Organization of the United Nations. (2016). Crops. FAOSTAT. http://www.fao.org/faostat/en/\#data/QC 
[9] Food and Agriculture Organization of the United Nations. (2019). Banana facts and fgures. Trade and Markets.

http://www.fao.org/economic/est/estcommodities/bananas/bananafacts/en/\#.XDkq51xKiM8

[10] https://www.telegraphindia.com/north-east/coronavirus-lockdown-pandemic-hits-bananamarket-in-goalpara/cid/1766873

[11] https://mbda.gov.in/how-group-farmers-transformed-banana-supply-chain-north-garo-hillsdistrict-meghalaya 